\title{
Store Atmospherics and Experiential Marketing: A Conceptual Framework and Research Propositions for An Extraordinary Customer Experience
}

\author{
Salomão Alencar de Farias ${ }^{1}$, Edvan Cruz Aguiar ${ }^{1} \&$ Francisco Vicente Sales Melo ${ }^{1}$ \\ ${ }^{1}$ Departament of Administrative Sciences, Federal University of Pernambuco, Brazil \\ Correspondence: Salomão Alencar de Farias, Departament of Administrative Sciences, Federal University of \\ Pernambuco, Address: Av. Prof. Moraes Rego, 1235, Cidade Universitária, CEP.: 50.670-901 Recife, Brazil. Tel: \\ 55-81-2126-8000. E-mail: saf@ufpe.br
}

Received: October 22, 2013

Accepted: December 24, 2013

Online Published: January 23, 2014

doi: $10.5539 /$ ibr.v7n2p 87

URL: http://dx.doi.org/10.5539/ibr.v7n2p87

\begin{abstract}
The components of a store atmosphere that can be manipulated to generate answers on individuals are related to sensory factors. Experiential marketing that enhances the sensory aspects of consumption helps in understanding the impact of retail environment on consumer behavior. Retailers around the world have embraced the concept of customer experience management, with many incorporating the notion into their mission statements, searching for the creation of a distinctive customer experience for their customers (Verhoef et al., 2009). The main objective of this paper is to propose a conceptual framework for an extraordinary customer experience. The construction of this theoretical paper was possible through the usage of desk research methodology. We reviewed the theory on store atmospherics and customer experience, both related to the retail setting, beginning on the 1950's and ending on 2011. We also provide some research propositions aiming to develop the knowledge in this field. It is concluded that it is imperative for retailers today to take in account customers' holistic experience as a relevant tool to manage the retail operation in a scenario of global competition.
\end{abstract}

Keywords: store atmosphere, retail, experiential marketing, consumer behavior

\section{Introduction}

Retailers have shown an increasing importance in the global business scene. Consisting of all the activities that comprise the process of selling products and services to meet a personal need of the individual consumer, the store formats and environment vary, and compete globally. Also, the retail space, meaning the proximate environment that surrounds the retail customer, is never neutral. It will always influence the individual. The retail store is a group of cues, messages, and suggestions that communicate to buyers. Retail store designers, planners, and merchandisers shape space, and that space in turn affects and shapes customer behavior. There is a reciprocation pattern (Markin, Lillis, \& Narayana, 1976).

The first academic articles on the impact of the store environment in consumer behavior date back to 1950 and 1960 (for example, Martineau, 1958; Cox, 1964; Smith \& Currow, 1966; Kotzan \& Evanson, 1969). In the following decade, Kotler (1973) in his seminal article "Atmospherics as marketing tool", coined the term "store atmosphere", that is used to describe the conscious planning of the environment to create certain effects in buyers, for that he is credited pioneering the subject (Turley \& Milliman, 2000). Kotler (1973) affirms that a product goes beyond the tangible aspects normally associated with it, adding in his definition a package that constitutes the "true product" perceived by consumers, including the planned environment where it is sold.

During the 80 's, a new perspective opens up the theory of consumer behavior-the hedonic perspective. Until then, buyers were thought to be exclusively rational beings, whose purchasing choices were made after a logical processing of available information into a stream that came from the detection of a problem to their satisfaction with the purchase (Schmitt, 1999; Solomon, 2008). Later research however showed that a number of non-rational factors exerted strong influence on buying behavior. Among these factors are hedonism, fantasies, feelings and fun (Holbrook \& Hirschman, 1982), the moods of consumers (Gardner, 1987), and consumption rituals (Rook, 1985). These findings have revolutionized the way of seeing the consumer, indicating the influence of "experiential" aspects in consumption, as defined by Holbrook and Hirschman (1982). 
Some authors such as Pine and Gilmore (1998) and Schmitt (1999), called our attention for what is known as era of "experiential" economics where products are no longer an end in themselves but are artifacts of a larger construct called consumption experience, which is memorable, personal, prolonged and involves many sensations. Today, we are experiencing this moment with studies that evidence the experiential aspects of consumption (Pullman \& Gross 2004; Hume et al., 2006; Voss, Roth, \& Chase, 2008; Zomerdijk \& Voss, 2010). Within an experiential marketing perspective, companies should take advantage of every point of interaction with consumers to create and reinforce this experience, either through sponsorship, merchandising, advertising and, especially, point of sale (Schmitt, 2004; Naylor et al., 2008).

The components of a store atmosphere that can be manipulated to generate certain responses to approach consumers are related to individual perception and sensory factors. For instance, a store can highlight the colors (and lighting), smells, and music (Kotler, 1973; Donovan \& Rossiter, 1982). Other factors such as textures and flavors are also in the context of the retail atmosphere, although still in need of scientific investigation. It is also emphasized that consumers express their identities, feelings, thoughts and motivations influenced by sensory experiences with past and present products and services, and companies now communicate their offerings to increase appeals to all senses. The "transformation" of new and existing products from companies to consumers has support in the ability to develop and realize their preferences in favor of the stimuli from marketing, cultural and social appeal to all senses.

There is no ideal model of store atmosphere to be followed or copied by managers of a retail or service environment. Decisions on the atmosphere components are part of a larger set of outcomes that are related to marketing strategy and for this reason should not be done in an informal and intuitive way (Chebat \& Dube, 2000) or relegated to secondary discussions, as a result of choices made by architects and decorators (Turley \& Chebat, 2002).

The sensory system (consumer perception) has already been investigated in the literature of consumer behavior since the beginning of the systematization of this theory (Solomon, 2008), and is considered "the gateway" of information around the individual as he perceives the world around him. Vision, hearing, olfaction, palate and tact are the senses that enable humans to understand the world, and they bring positive and negative feelings to a particular consumer experience. Thus, the sensory appeals present in a retail environment emerge as tools for the provision of experiences to consumers, which can bring competitive advantages, if treated differently and consistent with the target market segments.

The main objective of this paper is to propose a conceptual framework for an extraordinary customer experience. With this we intend to contribute to the studies in the retail area from the proposition of this model and the systematization of the literature reviewed. The construction of this paper was possible through the usage of desk research methodology. We reviewed the theory on store atmospherics and customer experience, both related to the retail setting, which allowed us to navigate through relevant journals in the investigated field, beginning on the 1950's and ending on 2011.

\section{Atmospherics and Retail Marketing}

What is an atmosphere? Atmosphere in marketing is a term used to describe the conscious design of an area in order to create a desired effect on consumers. It is the effort to design a shopping environment that produces emotional effects on the individual in order to increase their likelihood of purchase (Kotler, 1973). The store atmosphere is the stimulus that causes the consumer evaluation in relation to the environment, and some behavioral responses (Turley \& Milliman, 2000). A major reason for non-functional in store purchases corresponds to sensory stimulation. The store atmosphere can enhance the quality perceived by consumers, which leads to higher levels of persuasion (Sharma \& Stafford, 2000).

The atmosphere is always presented as the quality of space "around" and it is described in sensory terms. The main sensory channels to the atmosphere are vision, hearing, smell and touch. Specifically, the most relevant visual dimensions of the store atmosphere are: color, brightness, size and shapes. The main dimensions are: volume and pitch; Olfactory: smell and freshness; Tactile: softness, smoothness and temperature (Kotler, 1973).

The retail environment is being transformed with the introduction of multichannel operations designed to offer a spectrum of retail experiences for consumers to choose. In what has been dubbed an emerging "experience economy", we find retailers redefining themselves as a source of memories, rather than goods, as an "experience stager" rather than a service provider (Pine \& Gilmore, 1999). The traditional retail segment, for example, is being transformed into "retail interactive theater", staffed to offer advice, cooking lessons, beauty makeovers and fashion shows (Mathwick et al., 2001). As retail managers grapple with these demands, they are advised to keep in mind that the retail experience must transmit value if it is to turn a one-time visitor into a repeat customer. 
Perceived value has been characterized as the essential outcome of marketing activity (Babin, Darden, \& Griffin, 1994) and as a primary motivation for entering into marketing relationships.

It is necessary to remind that there is an important difference between "desired atmosphere" and "perceived environment" (Kotler, 1973). The first refers to the set of sensory qualities designed for the artificial environment in order to establish a specific "ambiance". On the other hand, perceived atmosphere can vary from one individual to another, one's reaction to colors, sounds, noise and temperature are partially learned, and they cannot be fully controlled by organizations (Zomerdijk \& Voss, 2010). The atmospheric characteristics of a store are relevant for they influence a wide variety of consumer evaluations and behaviors (Turley \& Milliman, 2000). Furthermore, the store atmosphere is represented psychologically by consumers in terms of two major emotional states - pleasure and arousal - and these two emotional states are significant mediators of intended shopping behaviors within the store (Donovan \& Rossiter, 1982).

How does the store atmosphere influences the consumer behavior? Through what mechanism does the store atmosphere affects buying behavior? Most of the time the purchased object (product or service), is placed in an area marked by certain sensory qualities, which may be intrinsic or may be designed by the company. Each individual perceives only certain qualities of that space, due to selective attention, distortion and retention. The perceived qualities can affect the information and the affective state of the consumer, which can lead to a greater propensity to purchase.

The store atmosphere affects the behavior in at least three aspects. First, it is useful as a mean to draw the attention of consumers through the use of colors, sounds, sights, smells, touch and movements, to differentiate themselves from others (Soars, 2009). Second, it is a mean of trasmitting the message that the store expresses a series of characteristics on its environment, specifically, the relationship between growth, location strategy, and market response (González-Benito, Muñoz-Gallego, \& Kopalle, 2005). Third, the atmosphere works as a mean to establish affective states, since the characteristics of an environment, as mentioned above, can trigger internal reactions that contribute positively to the likelihood of purchase, considering still that the store atmosphere should evoke phasic arousal reactions to attract consumers (Groeppel-Klein, 2005).

When planning the atmosphere, some questions should be considered: Who is the target audience? What is one looking for in terms of shopping experience? Which atmospheric variables can strengthen the beliefs and emotional reactions that buyers are looking for? (Kotler, 1973, p. 63). That is, these questions are actually steps to manage the atmosphere of the store. It can also be considered an important tool for creating value in a gaining share of costumer, depending on the impact that the consumers feel with environmental conditions (Babin $\&$ Attaway, 2000). The three main tools that contribute to achieving the goals of a traditional store atmosphere are: Architecture - the structure of the atmosphere outside of buildings; Decoration - the atmosphere inside the store; and Window Design - the atmosphere of the store (Kotler, 1973, p. 63).

Marketing researchers have come to realize that if consumers are influenced by physical stimuli experienced at the point of purchase, the practice of creating influential atmospheres should be an important marketing strategy for most exchange environments (Bitner, 1990; Donovan et al., 1994; Kumar \& Karande, 2000; Turley \& Milliman, 2000). This view is explained by the SOR paradigm, from the environmental psychology, according to which environmental stimuli (S) are processed by the organism $(\mathrm{O})$, resulting in behaviors towards or away from the individual in relation to the environment-response (R). According to Mehrabian and Russell (1974) environmental stimuli influence the emotional states of people represented in their PAD model with the dimensions $\mathrm{P}$ (pleasure), A (activation) and D (dominance), and determine their behavior in order to approach (affiliation, exploration, purchase) or removal/avoidance (disinterest, not purchase) of that environment. It is important to remind that the environmental stimuli of the store atmosphere are captured by consumers through the senses of sight (colors, shapes, and sizes), hearing (music), smell (aroma, odor) and touch (softness, temperature).

To Kotler (1973), a product goes beyond the tangible aspects normally associated with it, adding several other items, including a planned environment, a package that constitutes the "true product" perceived by consumers. Kotler's (1973) store atmosphere impact on the purchase probability is presented in Figure 1.

Mehrabian and Russell's (1974) seminal conceptualization is the basis of most researches on the impact of environmental factors on shopping behavior. They propose that the environment's sensory variables, the environment's information rate (the amount of information in the environment), and individual differences in people's affective responses to the environment, in turn induce people to approach or avoid a certain environment. 


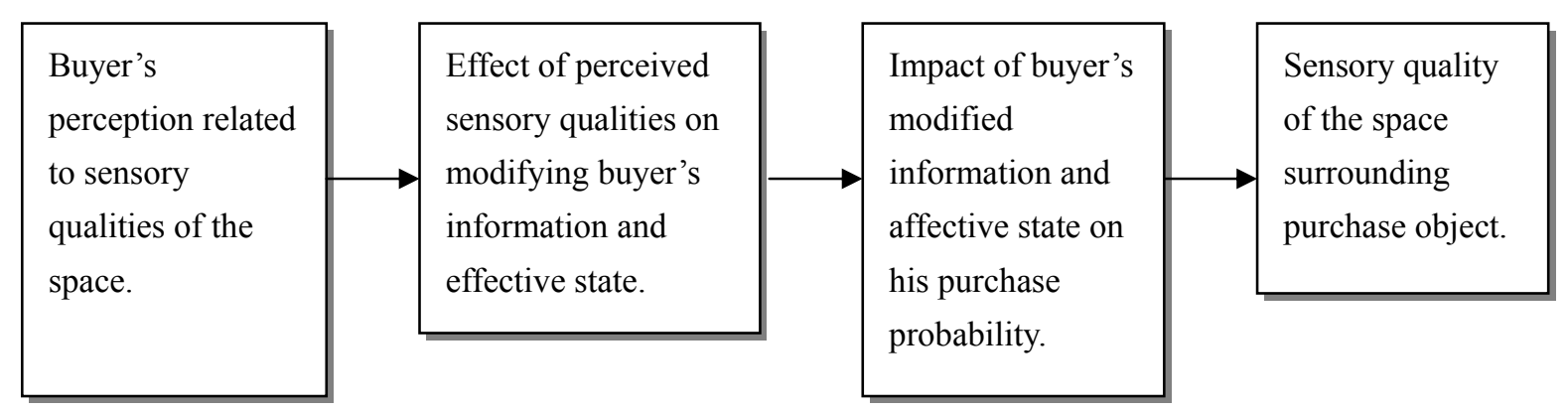

Figure 1. The causal chain connecting atmosphere and purchase probability

Source: Kotler (1973, p. 54).

As pointed before, Mehrabian and Russell (1974) identify three dimensions of affective response: pleasantness, arousal, and dominance. However, subsequent research has found that pleasantness and arousal explain most of the variance in affection and behavior, and thus research attention has been focused on these two variables (Russell, 1978).

Mehrabian and Russell's model (1974) was tested on the retail environment by various authors (for instance, Donovan \& Rossiter, 1982; Donovan et al., 1994; Kenhove \& Desdrumax, 1997) and as a conclusion it was found that consumer's response to pleasure, which represents how much the environment is pleasant or not to the consumer, and activation that shows if it is challenging or not, were the main outputs. In short, within a store, stimuli that lead to positive emotional responses also lead to approach behaviors, and stimuli that lead to negative emotional responses, on the other hand, lead to the behavior of removal from the store.

Kotler (1973) warns that even the atmospheres considered successful must undergo a periodic review, as its influence declines over time, depending on the customers getting used to it or the progress of competitors in the direction of more efficient and new atmospheres. Complete reformulation of atmosphere is not a simple challenge, but it has the ability to significantly alter the perception of the consumer on the store (Turley \& Chebat, 2002). The sensory system (consumer's perception) has been investigated since the beginning of consumer behavior theory systematization (Solomon, 2008) and it is considered the "gateway" of information surrounding the individual as he perceives the world around him. Vision, hearing, olfaction, palate and tact are the senses that enable humans to understand the world, and they bring positive and negative feelings to a particular consumer experience. Thus, the components present in a sensory retail environment emerge as tools for the provision of experiences to consumers, which can bring competitive advantages if worked differently and consistently with the market segments targeted.

Kaltcheva and Weitz (2006, p. 109) have discussed in their paper when a retailer should create an exciting store environment, and used three basic constructs for this to happen: motivational orientation, arousal and pleasantness. According to them, the arousal construct is used to designate two somewhat distinct phenomena in psychology. "Objective arousal" is defined as the release of energy collected in the tissues, a variable representing the level of nonspecific physiological response. "Subjective arousal" is defined as the subjective experience of energy mobilization. Mehrabian and Russell's (1974) framework involves subjective arousal. These authors define arousal as an affective dimension ranging from sleep to frantic excitement and use a self report scale to measure it.

"Pleasantness" is defined as the hedonic valence (pleasant or unpleasant) of the affective response to a stimulus; it is based on the extent to which the stimulus (the object of the affective response) enables people to achieve their salient goals. Stimuli that facilitate goal achievement are experienced as pleasant, whereas stimuli that impede goal achievement are experienced as unpleasant (Kaltcheva \& Weitz, 2006).

\section{Theoretical Dimensions of Store Atmosphere}

\subsection{Colors and Store Atmosphere}

Bellizi et al. (1983) argue that meaning is obtained through symbols. The communication occurs when symbols are exchanged between the source and receiver. Communication in marketing typically involves many symbols, forms of words, objects, sounds and colors in order to provide meanings. The colors produce different reactions in individuals (biological, emotional, and draw attention to an object). Thus, following the psychology outlines, retailers are trying to use colors to bring consumers to a mood state that leads to product purchase. Bellizzi and 
Hite (1992) tested the effects of red and blue in a shopping-related context. According to the authors, red is perceived as negative and tense as well as physically arousing. On the other hand, blue was identified as calm, cool and positive. The study of these authors has proved the physical attraction offered by colors, which is relevant to retailers, who must plan their promises so as to be attractive to customers, in order to offer an interesting shop experience. Crowley (1993) studied the impact of color on shopping and perceived that its effects are described as a function of color wavelength. Evaluative effects are most positive at the short wavelength (blue) end of the visible spectrum, while the activation response engendered by color exhibits a U-shaped pattern across wavelengths. In this sense, Babin, Hardesty and Suter (2003) examined the relation between color and shopping intentions and the findings indicated that there are several consumer reactions with the three-way congruence between a store's environmental cues, consumers' cognitive categories representing known store types, and salient situational shopping motivations. To Bellizi et al. (1983, p. 41), warm colors seem to be more preferred in attracting potential customers closer to the windows.

\subsection{Music and Store Atmosphere}

Playing the appropriate background music can help retailers develop a desirable atmosphere, which contributes to the image of the store and consumer choice. How can the background music help consumers fill their shopping needs? The answer is simple: playing the "right kind" of music, for there is evidence that this has a direct impact on consumer behavior (Harrington \& Capella, 1994). Attempts to explain this phenomenon leads to discussion of individual models of interaction with the environment, where people respond both voluntary and involuntary to environmental stimuli. Harrington and Capella (1994) discuss the practical implications of music in retail environments and services, highlighting the various features of music (emotional and physical) that has the potential to evoke desired behaviors in individuals.

Some studies have shown that atmospheric music can: increase sales (Matilla \& Wirtz, 2001); influence purchase intentions (Baker et al., 2002), increase the time to buy and hold (Milliman, 1982); decrease the perception of buying time and waiting (Chebat et al., 1993), influence the rate of consumption of a meal in restaurants (Milliman, 1986); influence consumer perception of a store (Hui et al., 1997); and facilitate consumer official interaction (Dube et al., 1995). Recently, some studies have examined the role of environmental background music and its importance in the consumer purchase (Chebat, Chebat, \& Vaillant, 2001; Alpert, Alpert, \& Maltz, 2005; Eroglu, Machleit, \& Chebat, 2005; Morin, Dubé, \& Chebat, 2007; Vacaro et al., 2009). These works have advanced and contributed to understanding the relationship between consumer perceptions and their responses on the products, behaviors intentions, store image and so on. Although these finds have implications for academics, it has not been systematically applied in the real world.

\subsection{Smell and Retail Environment}

According to Gulas and Bloch (1995), the olfactory stimulus is relevant to consumer behavior in two ways: the specific object smell and the smell of the environment itself. Smells emanated by objects or products are often a clue to the consumer quality and attribute evaluation of these objects, especially those where the smell is a major factor, such as food, beverages, cosmetics and cleaning products (Milotic, 2003). The smell in these environments may be from the product or not, since the technology is now enabling the use of artificial smells (Bosmans, 2006). Unlike the smell coming from the product, the environmental aroma can influence the reactions to any product sold in a store, even those which would be difficult or inappropriate to add an artificial scent. According to Baker and Parasuraman (1994) individual characteristics such as age, income, gender and culture can be determinant of how people associate quality and atmospheric elements.

For some researchers (e.g., Donovan \& Rossiter, 1982; Mitchell, 1994; Bosmans, 2006), the smell is primarily an environmental stimulus, whose influence on the consumer goes far beyond the communication of attributes or qualities of products. According to Mitchell (1994), matching environmental scents can lead to emotions and memories associated with rescue of the store and the product sold, encouraging the purchase, while incongruous smell can trigger emotions and recall irrelevant memories, not compatible with the store and products, and negatively affecting the purchase context. The effects of smells in retail environment were analysed and found to valuation and behaviors differences in some atmospheres with and without scent, serving as guidelines for managers in retail and service establishments that highlight the benefits of using scents in the store ambiance (Spangenberg, Crowley, \& Henderson, 1996).

The olfactive cues can exert a strong influence on the consumer responses related to a specific store atmosphere. Bone and Ellen (1999) argued that retailers, once perceiving the power of olfactory stimulus have searched competitive advantage throught this variable (Herrmann et al., 2013). For Morrison and Ratneshwar (2000), a store that presents smells that are pleasant is better evaluated by the consumer. The use of perfumes in the 
environment or odors in the atmosphere as means of influencing human behavior seems to be growing (Morrin \& Ratneshwar, 2000, p. 157).

Chebat and Michon (2003) tested the effect of ambient scents in a shopping mall environment and conclude that the cognitive theory of emotions better explains the effect of ambient scent. Smells emanated by objects or products are often a clue to consumer evaluation of the quality and attributes of these objects, especially those where the smell is a major factor, such as food, beverages, cosmetics and cleaning products (Milotic, 2003). To Bosmans (2006) odors present in stores can be derived from the sold product, but not necessarily, since todays' technology allows the use of artificial odors.

\section{Experiential Marketing}

Verhoef et al. (2009, p 31) affirms that retailers around the world have "embraced the concept of customer experience management, with many incorporating the notion into their mission statements", searching for the creation of a distinctive customer experience for their clientele. They also point that "creating a superior customer experience seems to be one of the central objectives in today's retailing environments". Despite the recognition of the importance of customer experience by companies, the academic marketing literature investigating this topic has been limited. Pine and Gilmore (1999) indicated that creating a unique customer experience can provide financial value for the company.

Since the mid-80's, researchers of consumer behavior have sought to enhance the research approach of this area that sees consumers primarily as rational decision makers. Addis and Holbrook (2001) presented a model of experiential consumption, considering that this approach becomes increasingly important for marketing, where it should be recognized emotions and feelings that individuals bring to their interactions with the products. This way, the greater the importance of subjective responses from clients, the greater the prominence of the hedonic aspects of the consumption experience.

Currently consumption is recognized as consisting primarily of two phases: the relationship between the consumer and business, and the use of the core product. That is, the consumption extends the consumer's relationship with the company with bundled services, communication, etc. and the use of the product involves the inclusion of other offerings that create a consumption experience, a constellation of products (Addis \& Holbrook, 2001)

According to them, in every event, consuming involves an interaction between a subject and an object, or the subject and the consumer or client and the object and the good, service, event, person, place or whatever. The product has certain objective features such as color, price, weight, shape and so on, while the consumer personality embodies equipped with sensitivity to different types of subjective responses, this relates with utility and hedonic consumption.

Consumption utility means consume utilitarian products. Hedonic consumption is related to the multi-sensory aspects, i.e., the experience received in multiple sensory modalities including flavors, tactile impressions and visual images. Addis and Holbrook (2001, p. 61) have presented the guidelines for decision-making that refers to the consumption utility and experiential visions specially related to hedonic consumption. With this, a new version of marketing has emerged, the experiential marketing, focusing on consumers' experiences in a holistic and eclectic way, where experience means "private events that occur due to some stimulus (such as marketing efforts before and after purchase)". Moreover, the experiential realm of the consumer is enriched by the role of the symbolism.

All kinds of business can provide experiences, taking in account that the economy is evolving into the era of experiences, especially due to technology, increasing competition intensity, change of products, services and for now, experiments, and also due to increased consumers' affluence. In other words, nowadays researchers and marketers must use the experiential view of consumption for different products, in complement to the traditional approach of model driven decision making.

On a study conducted by Yuan and $\mathrm{Wu}$ (2008), the authors presented the relationship between experiential marketing, experiential value and customer satisfaction. According to them, experience is the main component of experiential marketing. Businesses usually create special stages for customers to experience through different stimulations, including environments, atmospheres, and layouts. As a result of experiencing, customers have different perceptions and reactions to these stimulations. When they walk into these stores, or even close to them, they develop varied perceptions about them. Customers' perceptions should be the outcome of marketing efforts that businesses have made. The concept of experiential marketing has been applied to many areas, such as retailing, branding, and event marketing. 
Experiential marketing differs from traditional marketing in four major ways-marketing focus, product categories and competition, customer characteristics, and research method (Schmitt, 1999). This late author defined experiential marketing as customers' developing recognition of and purchasing goods or services from a company or brand after they experience activities and perceive stimulations. Experiential marketing motivates customers to make faster and more positive purchasing decisions.

According to Meyer and Schwager (2007) customer experience is the internal and subjective response customers have to any direct (planned encounters) or indirect contact (unplanned encounters) with the company. This way, one can say that customer experience construct is holistic in nature and involves the customer's cognitive, affective, emotional, social and physical response to the retailer (Verhoef et al., 2009).

Berry et al. (2002) point that in recent years managers have become increasingly aware of the need to create value for their customers in the form of experiences, and for that to happen they must understand the consumer's journey from the expectations before the actual buying experience and the offer of the experience.

Atmospherics, or the retail store environment, refer to both tangible and intangible aspects of a retail store design and can alter the customer experience. An array of retail environmental features influences the subjective experience of consumers, especially their pleasure and arousal (Mehrabian \& Russell, 1974). Specifically, for instance, environmental stimuli (e.g., store lighting) can influence a consumer's emotional state (e.g., pleasure, arousal), which in turn drives the consumer's approach or avoidance behavior (e.g., willingness to buy) (Puccinelli et al., 2009).

\section{Management of Customer Experience in the Retail Setting}

Understanding and enhancing the customer experience "sits atop most marketing and chief executives' agendas, both in consumer packaged goods manufacturing and retailing fields and it remains a critical area for academic research" (Grewal et al., 2009, p. 1). It is known now that consumers appear to perceive servicescapes (Bitner, 1992) in an ambient, in a holistic manner, such that they have direct and mediate effects on outcomes (Puccinelli, 2009 , p. 24). Store atmosphere can interact with consumer perceptions to affect behavior. In particular, store atmosphere perceptions positively, whereas wait expectations negatively predict patronage intentions (Baker et al., 2002).

The elements under control of the retailer (retail atmosphere) are usually those related to the customer' senses. For instance, the store can manage the amount of light, the colors on the walls, the kind of music played on the background, etc. This is the start point in the process of managing the costumer's experience (the model presented in Figure 2 shows the retail atmosphere as the first step in offering an extraordinary retail experience). Besides that, other constructs influence the total experience in the retail setting. Situation moderators as the type of store, location, economic climate, convenience, time of the year can impact the experience (Kaltcheva \& Weitz, 2006). Also consumer moderators related to the type of buying process, the consumer's goal, for instance, task oriented (rational) or experiential (hedonic), which is related to the motivational orientation: two fundamental motivational orientations underlie the different shopping motives. The first motivational orientation (e.g., economic, utilitarian) involves consumers engaging in shopping out of necessity to obtain needed products, services, or information with little or no inherent satisfaction derived from the shopping activity itself. Kaltcheva and Weitz (2006) refer to this motivational orientation as the "task-oriented motivational orientation". The other motivational orientation (e.g., recreational, hedonic) describes consumers engaging in shopping to derive inherent satisfaction from the shopping activity itself. In this case, the shopping activity is freely chosen, and there is no need to engage in it. This is the "recreational motivational orientation", affirm the same authors.

Adding to this, the consumer experience contains the consumer attitudes, level of involvement on the purchase, innovativeness, price sensitiveness, etc. The holistic environment on Figure 2 refers to other components of the retail atmosphere, most of the time without control of the management. First there is the social environment that involves reference groups, tribes, service personnel and other customers. Verhoef et al. (2009) suggest the need to better understand the role of other consumers in the shopping experience. They note that the presence of other consumers can have a negative or destructive effect on the shopping experience.

Second there is the need to manage the service interface that includes the service person, the kind of technology offered at the retail setting, the possibility of co-creation and customization. Third there is the price management - mainly loyalty programs and promotions that could lead to an extraordinary experience. A price set too low may signal low quality, poor performance, or other negative attributes about the product or service. Although setting the "right" price is clearly an important retailing task, "it is often treated as an afterthought, partly because it remains the least understood and therefore most difficult to manage task" (Grewal et al., 2009). 
Forth the conceptual framework embraces the assortment - variety of product, uniqueness, and its quality, where the manager has control. Retail environmental factors always affect business decisions, though several have become particularly salient in today's retail environment. Many retailers adopt categories that traditionally were carried by retailers using other formats, such as drug stores carrying food items. "This practice provides a more comprehensive assortment for customers, but it also makes it more difficult for them to distinguish one store or retail format from another" (Grewal et al., 2009, p. 6). Finally there are the retail brand and the customer experience in alternative channels (on-line retail) (Verhoef et al., 2009), as part of the situation moderators.

The customer experience itself in the center of Figure 2 and it deals with cognitive, affective, social and physical issues. Here the individual can experience arousal and pleasure with the shopping process that will result in sense of relief and other related physical reactions.

It is important to stress that an extraordinary customer experience consists of what is memorable and that can lead to a purchase behavior. It is subjective and the retailer does not have complete control of it. As shown in the framework, different constructs can influence the customer experience, and the extraordinary experience is a holistic result of their interaction.

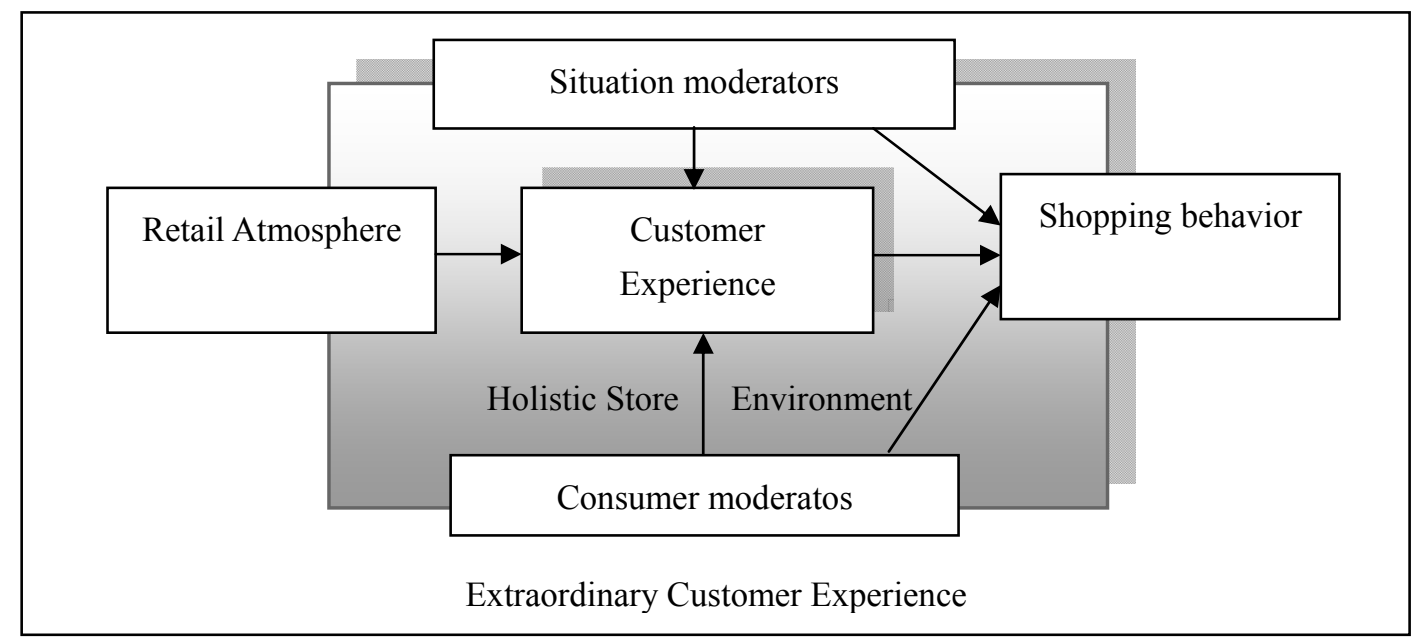

Figure 2. Conceptual framework for an extraordinary retail experience

Source: author based on Verhoef et al. (2009, p. 32).

The shopping behavior implies in consumer actual behavior: approach or avoidance to the store environment as part of the total experience. Approach here means buying a product at the retail setting as a result of a pleasant experience. Avoidance on the other hand means not buying a product due to a poor experience. It is important to stress that the shopping act, the consumption of the product and post-purchase evaluations are all part of the consumer holist experience with the retail.

This way, to manage the customer experience in order to offer an extraordinary experience, all the previous variables must be considered. It is not an easy task for the managers, but in today's competitive environment, trying to differentiate from competitors with the offer or a memorable experience can make a huge difference for a business.

Figure 2 shows a synthesis of the main constructs involved on the consumer experience on the retail setting, portraying that retail atmosphere has an impact on customer experience, that is moderated by situation and consumer moderators, that also influence the shopping behavior as the ultimate output. It is important to stress that customer experience is also related to the shopping behavior. Finally, we cannot forget to mention the holist store environment, usually a set of uncontrollable variables that affects consumer behavior.

\section{Conclusion}

Consumers want to be sold on more than just attributes; they want to be "entertained, stimulated, emotionally affected and creatively challenged" (Schmitt, 1999, p. 29). In order to appeal to the emotions of the consumer, "the experience must be conveyed". Berry et al. $(2002$, p. 85$)$ affirm that "an organization's first step toward managing the total customer experience is recognizing the clues it is sending to customers". They continue to say 
that managers have become increasingly aware of the need to create value for their customers in form of experiences, not always the right way, "since they have often proceeded as if managing experiences simply mean to provide entertainment or being engagingly creative".

To conclude this paper we now present some research propositions related to the constructs listed on the conceptual framework previously shown.

It is paramount to begin with an important research opportunity that is to develop a scale that aims to measure the customer's retail experience in a holistic way. This will be the main challenge resulting from this paper: how to put together a scale that captures the customer experience as a whole, holistically. This way the first research proposition is: P1-Develop a scale that captures the holistic customer experience. To compete successfully, a growing number of organizations are systematically applying the principles and tools of customer-experience management. The holistic nature of these experiential designs makes them very difficult for competitors to copy (Berry et al., 2002).

Another research proposition would be to verify the impact of the retail atmosphere on the customer experience. Individually measure store smell, light, music and texture and then associate them to the customer experience. Is there a relationship between retail controllable variables and the customer experience? The second proposition is: P2-Measure the impact of retail atmosphere controllable variables (related to consumer's senses) on customer experience. The retail atmosphere can be a useful tool in building the consumer behavior and can have an important role or perceived shopping value in mediating the relationship (Babin \& Attaway, 2000).

Situational moderators should also be the subject of future research. Situation moderators as the type of the store, location, economic climate, convenience, time of the year can impact the experience according to the literature review. This way, using different kind of retail settings, locations and time of the year to measure the customer experience and compare the results of a longitudinal study is something needed on the academic field. The third proposition would be: P3 - Verify how the customer experience vary according to the type of store, location and time of the year. This would require a longitudinal research effort. This proposition is justified by the fact that although there are debates about whether the atmosphere can influence costumers in an environment, studies are necessary to clearly state that the atmosphere has an effect on consumer spending and how variations of atmospheric variables affect the amount of money that people spend and the number of items they purchase (Turley \& Milliman, 2000).

Also consumer moderators related to the type of buying process, the consumer's goal, for instance, task oriented (rational) or experiential (hedonic), which is related to motivational orientation should be taken in account when one studies the customer experience. Experiences can differ if the motive for the buying process is rational or hedonic. P4-Academic research is in need considering task oriented or experiential shopping and its effects on customer experience. Is it possible that only a hedonic orientation would lead to extraordinary?

There is also the need to better understand the role of other consumers in the shopping experience. Which role does the presence of other consumers (reference groups, tribes, service personnel) has on the shopping experience? P5-Analyze the impact of other consumers on shopping experience. Verhoef et al. (2009) affirm that the management of the social environment is important to influence customer experiences. Corroborating to these authors, Zomerdijk and Voss (2010) affirm that the presence of fellow customers can enhance or damage customer experiences.

Besides that, the service interface that includes the service person, the kind of technology offered at the retail setting, the possibility of co-creation and customization, should also be taken in account. Proposition 6 is presented as follow: P6.1-Investigate how the service person relates to the customer experience. P6.2-Investigate how the kind of technology offered by the retailer affects the customer experience. P6.3-Investigate how the possibility or co-creation or customization impact customer experience.

Another topic sometimes underestimated on the experience literature is the price-mainly loyalty programs and promotions that could lead to an extraordinary experience. A price set too low may signal low quality, poor performance, or other negative attributes about the product or service. This way, P7-Define the role of price management on the holistic customer experience. Another topic in need for academic research is the assortment-variety of product, uniqueness, and its quality. P8 - In what way does the assortment of products influence the customer experience?

Concluding this paper, it is important to say that we highlighted some important contributions on the retail literature, both related to store atmosphere and customer experience that ultimately resulted on a conceptual framework for an extraordinary customer experience and some research propositions. 
In order to advance the discussions on the subject, the propositions refers to reflections for further studies. Furthermore, we believe that the conceptual framework proposed may also assist in organizational management, especially when it aims to provide an extraordinary experience for the consumer at the time of purchase. In future studies, other variables can be analyzed in order to identify which of them can influence the consumer experience, such as crowding, impact of the presence of others in the social environment, social action for minorities, mobility in the retail environment, among others).

\section{References}

Addis, M., \& Holbrook, M. B. (2001). On the conceptual link between mass customization and experiential consumption: an explosion of subjectivity. Journal of Consumer Behavior, 1(1), 50-66. http://dx.doi.org/10.1002/cb.53

Alpert, M. I., Alpert, J. I., \& Maltz, E. N. (2005). Purchase occasion influence on the role of music advertising. Journal of Business Research, 58(3), 369-376. http://dx.doi.org/10.1016/S0148-2963(03)00101-2

Babin, B. J., Hardesty, D. M., \& Suter, T. A. (2003). Color and shopping intentions: The intervening effect of price fairness and perceived affect. Journal of Business Research, 56(7), 541-551. http://dx.doi.org/10.1016/S0148-2963(01)00246-6

Babin, B. J., \& Attaway, J. S. (2000). Atmospheric Affect as a Tool for Creating Value and Gaining Share of Customer. Journal of Business Research, 49(2), 91-99. http://dx.doi.org/10.1016/S0148-2963(99)00011-9

Baker, J., \& Parasuraman, D. G. A. (1994). The influence of store environment on quality inferences and store image. Journal of the Academy of Marketing Science, 22(4), 328-339. http://dx.doi.org/10.1177/0092070394224002

Baker, J., Parasuramen, A., Grewal, D., \& Voss, G. B. (2002). The influence of multiple store environment cues on perceived merchandise value and patronage intentions. Journal of Marketing, 66(2), 120-141. http://dx.doi.org/10.1509/jmkg.66.2.120.18470

Bellizzi, J. A., \& Hite, R. E. (1992). Environmental Color, Consumer, Feelings and Purchase Likelihood. Psychology and Marketing, 9(5), 347-363. http://dx.doi.org/10.1002/mar.4220090502

Berry, L. L., Carbone, L. P., \& Haeckel, S. H. (2002). Managing the total customer experience. Spring 2002, 43(3).

Bitner, M. J. (1990). Evaluating Service Encounters: The Effects of Physical Surroundings and Employee Responses. Journal of Marketing, 54(2), 69-82. http://dx.doi.org/10.2307/1251871

Bitner, M. J. (1992). Servicescapes: the impact of physical surroundings on customer and employees. Journal of Marketing, 56(2), 57-71. http://dx.doi.org/10.2307/1252042

Bone, P. F., \& Ellen, P. S. (1999). Scents in the Marketplace: Explaining a Fraction of Olfaction. Journal of Retailing, 75(2), 243-262. http://dx.doi.org/10.1016/S0022-4359(99)00007-X

Bosmans, A. (2006). Scents and sensibility: when do (in) congruent ambient scents influence product evaluations? Journal of Marketing, 70(3), 32-43. http://dx.doi.org/10.1509/jmkg.70.3.32

Chebat, J., \& Dube, L. (2000) Evolution and challenges facing retail atmospherics: the apprentice sorcerer is dying. Journal of Business Research, 49(2), 89-90. http://dx.doi.org/10.1016/S0148-2963(99)00012-0

Chebat, J., Chebat, C. G., \& Vaillant, D. (2001). Environmental background music and in-store selling. Journal of Business Research, 54(2), 115-123. http://dx.doi.org/10.1016/S0148-2963(99)00089-2

Cox, K. (1964). The responsiveness of food sales to shelf space changes in supermarkets. Journal of Marketing Research, 1(2), 63-67. http://dx.doi.org/10.2307/3149924

Crowley, A. E. (1993). The two-dimensional impact of color on shopping. Marketing Letters, 4(1), 59-69. http://dx.doi.org/10.1007/BF00994188

Donovan, R. J., \& Rossiter, J. R. (1982). Store atmosphere: an environmental psychology approach. Journal of Retailing, 58(1), 34-57.

Donovan, R. J., Rossiter, J. R., Marcoolyn, G., \& Nesdale, A. (1994). Store atmosphere and purchasing behavior. Journal of Retailing, 70(3), 283-294. http://dx.doi.org/10.1016/0022-4359(94)90037-X

Dube, L., Chebat, J. C., \& Morin, S. (1995). The effects of background music on consumers' desire to affiliate in

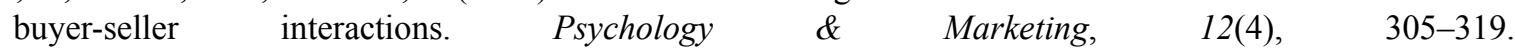
http://dx.doi.org/10.1002/mar.4220120407 
Eroglu, S. A., Machleit, K. A., \& Chebat, J. (2005). The Interaction of Retail Density and Music Tempo: Effects on Shopper Responses. Psychology \& Marketing, 22(7), 577-589. http://dx.doi.org/10.1002/mar.20074

González-Benito, Ó., Muñoz-Gallego, P. A., \& Kopallw, P. K. (2005). Asymmetric competition in retail store formats: Evaluating inter- and intra-format spatial effects. Journal of Retailing, 81(1), 59-73. http://dx.doi.org/10.1016/j.jretai.2005.01.004

Grewal, D., Baker, J., Levy, M., \& Voss, G. (2003). The Effects of Wait Expectations and Store Atmosphere Evaluations on Patronage Intentions in Service-Intensive Retail Stores. Journal of Retailing, 79(4), 259-268. http://dx.doi.org/10.1016/j.jretai.2003.09.006

Grewal, D., Levy, M., \& Kumar, V. (2009). Customer experience management in retail: an organizing framework. Journal of Retailing, 85(1), 1-14. http://dx.doi.org/10.1016/j.jretai.2009.01.001

Groeppel-Klein, A. (2005). Arousal and consumer in-store behavior. Brain Research Bulletin, 67(5), 428-437. http://dx.doi.org/10.1016/j.brainresbull.2005.06.012

Gulas, C. S., \& Block, P. H. (1995). Right under our noses: ambient scent and customer response. Journal of Business and Psychology, 10(1), 87-98. http://dx.doi.org/10.1007/BF02249272

Herrington, J. D., \& Capella, L. M. (1994). Practical Applications of Music in Service Settings. Journal of Services Marketing, 8(3), 50-65. http://dx.doi.org/10.1108/08876049410065615

Herrmann, A., Zidansek, M., Sprott, D. E., \& Spangenberg, E. R. (2013). The power of simplicity: processing fluency and the effects of olfactory cues on retail sales. Journal of Retailing, 89(1), 30-43. http://dx.doi.org/10.1016/j.jretai.2012.08.002

Hui, M. K., Dube, L., \& Chebat, J. (1997). The impact of music on consumer's reaction to waiting for services. Journal of Retailing, 73(1), 87-104. http://dx.doi.org/10.1016/S0022-4359(97)90016-6

Hume, M., Gillian, S. M., Peter, W. L., \& Hume, W. (2006). Understanding service experience in non-profit performing arts: implications for operations and service management. Journal of Operations Management, 24(4), 304-324. http://dx.doi.org/10.1016/j.jom.2005.06.002

Kaltcheva, V., \& Weitz, B. (2006). When should a retailer create an exciting store environment? Journal of Marketing, 70(1), 107-118. http://dx.doi.org/10.1509/jmkg.2006.70.1.107

Kenhove, P. V., \& Desrumaux, P. P. (1997). The relationship between emotional states and approach or avoidance responses in a retail environment. The International Review of Retail, Distribution and Consumer Research, 7(4), 351-368. http://dx.doi.org/10.1080/095939697342932

Kotler, P. (1973). Atmospherics as a marketing tool. Journal of Retailing, 49(4), 48-64.

Kotzan, J. A., \& Evanson, R. V. (1969). Responsiveness of drug store sales to shelf space allocations. Journal of Marketing Research, 6(4), 465-469. http://dx.doi.org/10.2307/3150084

Kumar, V., \& Karande, K. (2000). The effect of retail store environment on retailer performance. Journal of Business Research, 49(2), 167-181. http://dx.doi.org/10.1016/S0148-2963(99)00005-3

Markin, R. J., Lillis, C. M., \& Narayama, C. L. (1976). Social-Psychological significance of store space. Journal of Retailing, 52(1), 43-54.

Martineau, P. (1958). The personality of the retail store. Harvard Business Review, 36(1), 47-55.

Mathewicka, C., Malhotra, N., \& Rigdon, E. (2001). Experiential value: conceptualization, measurement and application in the catalog and Internet shopping environment. Journal of Retailing, 77(1), 39-56. http://dx.doi.org/10.1016/S0022-4359(00)00045-2

Matilla, A. S., \& Wirtz, J. (2001). Congruency of scent and music as a driver of in-store evaluations and behavior. Journal of Retailing, 77(2), 273-289. http://dx.doi.org/10.1016/S0022-4359(01)00042-2

Mehrabian, A., \& Russell, J. A. (1974). An Approach to Environmental Psychology. Cambridge, MA: MIT Press.

Meyer, C., \& Schwagner, A. (2007). Understanding customer experience. Zurich: Harvard Business Review.

Milliman, R. E. (1982). Using background music to affect the behavior of supermarket shoppers. Journal of Marketing, 46(3), 86-91. http://dx.doi.org/10.2307/1251706

Milotic, D. (2003). The impact of fragrance on consumer choice. Journal of Consumer Behaviour, 3(2), 179-191. http://dx.doi.org/10.1002/cb.131

Mitchell, D. J. (1994). For the smell of it all: functions and effects of olfaction in consumer behavior. Advances 
in Consumer Research, 21, 330.

Morin, S., Dubé, L., \& Chebat, J. (2007). The role of pleasant music in servicescapes: a test of the dual model of environmental perception. Journal of Retailing, 83(1), 115-130. http://dx.doi.org/10.1016/j.jretai.2006.10.006

Naylor, G., Kleiser, S. B., Baker, J. B., \& Yorkston, E. (2008). Using transformational appeals to enhance the retail experience. Journal of Retailing, 84(1), 49-57. http://dx.doi.org/10.1016/j.jretai.2008.01.001

Pine, B. J. II., \& Gilmore, J. H. (1998). Welcome to the experience economy. Harvard Business Review, 76(4), 97-105.

Puccinelli, N. M., Goodstein, R. C., Grewal, D. P., Robert, R. P., \& Stewart, D. (2009). Customer experience management in retailing: understanding the buying process. Journal of Retailing, 85(1), 15-30. http://dx.doi.org/10.1016/j.jretai.2008.11.003

Pullman, M. E., \& Michael, A. G. (2004). Ability of experience design elements to elicit emotions and loyalty behaviors. Decision Sciences, 35(3), 551-578. http://dx.doi.org/10.1111/j.0011-7315.2004.02611.x

Rook, D. W. (1985). The ritual dimension of consumer behavior. Journal of Consumer Behavior, 12(3), 251-264.

Russell, J. A. (1978). Evidence of convergent validity on the dimensions of affect. Journal of Personality and Social Psychology, 36(10), 1152-1168. http://dx.doi.org/10.1037/0022-3514.36.10.1152

Schmitt, B. H. (1999). Experiential marketing: How to get customers to sense, feel, think, act, and relate to your company and brands. New York: Free Press.

Smith, P. C., \& Curnow, R. (1996). "Arousal Hypothesis" and the effects of music on purchasing behavior. Journal of Applied Psychology, 50(3), 255-256. http://dx.doi.org/10.1037/h0023326

Soars, B. (2009). Retail insight: driving sales through shopper's sense of sound, sight, smell and touch. International Journal of Retai \& Distribution Management, 37(3), 286-298. http://dx.doi.org/10.1108/09590550910941535

Solomon, M. R. (2008). Consumer Behavior: buying, having and being (8th ed.). New York: Prentice Hall.

Spangenberg, E., Crowley, A. E., \& Henderson, P. W. (1996). Improving the store environment: do olfactory cues affect evaluations and behaviors? Journal of Marketing, 60(2), 67-80. http://dx.doi.org/10.2307/1251931

Turley, L. W., \& Chebat, J. (2002). Liking retail strategy, atmospheric design and shopping behavior. Journal of Marketing Management, 18, 125-144. http://dx.doi.org/10.1362/0267257022775891

Turley, L. W., \& Milliman, R. E. (2000). Atmospherics effects on shopping behavior: a review of the experimental evidence. Journal of Business Research, 49(2), 193-211. http://dx.doi.org/10.1016/S0148-2963(99)00010-7

Vaccaro, V. L., Yucetepe, V., Torres-Baumgarten, G., \& Lee, M. (2009). The impact of atmospheric scent and music-retail consistency on consumers in a retail or service environment. Journal of International Business and Economics, 9(4), 185-197.

Verhoef, P. C., Lemon, K. N., Parasuraman, A., Roggenvenn, A., Tsiros, M., \& Schlesinger, L. (2009). Customer experience creation: determinants, dynamics and management strategies. Journal of Retailing, 85(1), 31-41. http://dx.doi.org/10.1016/j.jretai.2008.11.001

Voss, C., Aleda, V. R., \& Richard, B. C. (2008). Experience, service operations strategy, and services as destina $\neg$ tions: foundations and exploratory investigation. Production and Operations Management, 17(3), 247-266. http://dx.doi.org/10.3401/poms.1080.0030

Westbrook, R. A., \& Black, W. C. (1985). A motivation-based shopper typology. Journal of Retailing, 61(1), 78-103.

Yuan, Y., \& Wu, C. (2008). Relationships among experiential marketing, experiential value and customer satisfaction. Journal of Hospitality and Tourism Research, 32(3), 387-410. http://dx.doi.org/10.1177/1096348008317392

Zomerdijk, L. G., \& Voss, C. A. (2010). Service design for experience-centric services. Journal of Service Research, 13(1), 67-82. http://dx.doi.org/10.1177/1094670509351960 


\section{Copyrights}

Copyright for this article is retained by the author(s), with first publication rights granted to the journal.

This is an open-access article distributed under the terms and conditions of the Creative Commons Attribution license (http://creativecommons.org/licenses/by/3.0/). 